\title{
The prognostic value of pro-calcitonin, CRP and thyroid hormones in secondary peritonitis: a single-center prospective study
}

\author{
Idris Akcay, M.D.,, Alexis K. Okoh, M.D., ${ }^{2}$ Orcun Yalav, M.D., ${ }^{3}$ Ismail C. Eray, M.D., ${ }^{3}$ \\ Ahmet Rencuzogullari, M.D., ${ }^{3}$ Kubilay Dalci, M.D., ${ }^{3}$ Hasan Elkan, M.D., ${ }^{4}$ Ali H. Alparslan, M.D. ${ }^{3}$
}

\begin{abstract}
'Department of General Surgery, Dr. Yaşar Eryılmaz Doğubeyazıt State Hospital, Ağrı;
2Department of General Surgery, Ankara University Faculty of Medicine, Ankara;

${ }^{3}$ Department of General Surgery, Çukurova University Faculty of Medicine, Adana;

${ }^{4}$ Department of General Surgery, Balıklıgöl State Hospital, Şanlıurfa
\end{abstract}

\begin{abstract}
BACKGROUND: Infections and sepsis remain the leading cause of morbidity and mortality in secondary peritonitis. Clinicians are still challenged with the task of finding an early and reliable diagnosis of septic complications. The role of inflammatory markers (Procalcitonin (PCT), C-reactive Protein (CRP) and thyroid hormones in determining the severity of secondary peritonitis was evaluated in this study.
\end{abstract}

METHODS: On the preoperative and first, third, fifth, seventh, and fourteenth postoperative days, PCT, CRP, and thyroid hormone concentrations were measured in serum taken from eighty-four consecutive patients who were operated on for secondary peritonitis between January 2008 and January 2010. All data was entered and analyzed using the Statistical Package for Social Sciences, version 15.0 and clinical parameters were compared using the student's t-test.

RESULTS: For the groups diagnosed with perforated viscus, PCT concentrations were significantly low in contrast to high thyroid hormone levels in patients who developed postoperative complications or died when compared to patients whose postoperative course was uneventful or discharged. The PCT concentration significantly correlated with the CRP concentration and WBC count.

CONCLUSION: In the absence of postoperative complications, PCT is a better predictor of outcome than CRP in secondary peritonitis. Our study showed that a low thyroid hormone level can serve as an important prognostic parameter of disease severity in secondary peritonitis.

Key words: C-reactive protein; procalcitonin; secondary peritonitis; thyroid hormone.

\section{INTRODUCTION}

Secondary peritonitis, a condition caused by the spread of bacteria and contents of intraabdominal organs into the peritoneal cavity, is one of the most important causes of abdominal sepsis carrying a higher risk of mortality and morbidity

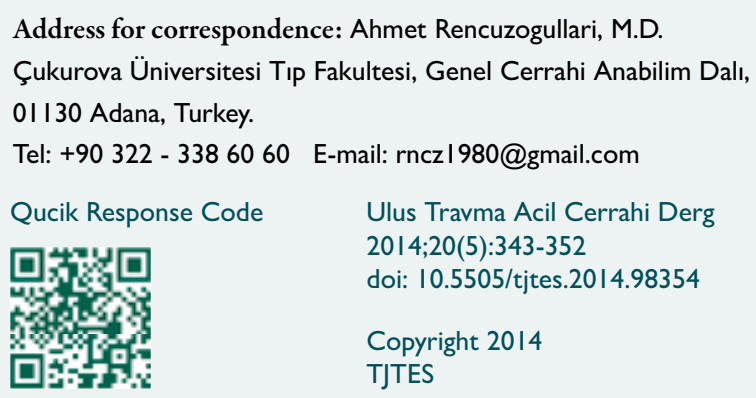

in surgical intensive care units. ${ }^{[1]}$ Mortality in secondary bacterial peritonitis is reported to be over $60 \%$ and known to correlate with the severity of the disease usually accessed by scoring systems such as the APACHE II/III and Mannheim Peritonitis Index (MPI). ${ }^{[2]}$ Other highly specific diagnostic modalities such as radiological imaging procedures or percutaneous aspiration have been proven to be useful tools in predicting overall disease severity and outcome.

An early and reliable diagnosis, together with a prompt and adequate treatment including immediate surgical repair of the underlying abdominal pathology, significantly contributes to a decreased mortality and morbidity. ${ }^{[3]}$ The management of postoperative complications or new onset abdominal sepsis occurring in patients after initial surgical repair still remains a compelling issue to the attending surgeon. The need for novel approaches to overcome this clinical dilemma has arisen 
and recent studies have investigated the role of easy, fast, and non-invasive diagnostic modalities in predicting the outcome during postoperative course. Non-specific signs of sepsis and infections include clinical symptoms such as fever, tachycardia, tachypnea, and leukocytosis on laboratory findings. Scoring systems have been proven to be useful tools in predicting overall disease severity and outcome; however, they fail to distinguish between infectious and non-infectious related complications. In contrast, other highly specific diagnostic modalities such as radiological imaging procedures or percutaneous aspiration techniques are costly, carry a considerable risk of complications and pose an additional stress on the patients. ${ }^{[2,4,5]}$

Facing this clinical quandary, the clinical appraisal of inflammatory markers in helping to establish a fast, reliable, and non-invasive diagnosis algorithm for sepsis in surgical patients has gained considerable interest among clinicians since the late 1980s. Among the large array of inflammatory parameters, CRP and PCT have obtained special interest in identifying patients at risk for severe complications following surgical intervention of secondary peritonitis. ${ }^{[6-8]}$

PCT, under normal conditions, is the II6-amino acid peptide precursor of the biologically active hormone calcitonin secreted by the c-cells of the thyroid gland. With the advent of the semi-automated assay technique, PCT assessment has become feasible in recent years. Its levels are relatively low in healthy subjects but known to increase in patients with bacterial infections or sepsis and fall dramatically after appropriate antimicrobial therapy. ${ }^{\left[{ }^{[]}\right.}$However, PCT levels do not change in response to severe viral infections or other inflammatory response syndromes. Hence, PCT has been confirmed as the only biochemical indicator closely correlating with the inflammatory host response to bacterial infections. ${ }^{[10-12]}$

Low levels of thyroid hormones have been reported in cases of sepsis, severe stress, trauma, and critical conditions such as cirrhosis. Euthyroid sick syndrome is characterized by abnormal thyroid findings in the presence of non-thyroidal illness (NTIs) without evidence of pre- existing hypothalamic pituitary conditions. The most common alternations are low T3, normal or low T4, and normal TSH levels. Studies have described a relationship between the severity of NTIs and low T3 and T4 levels with T3 and T4 levels gradually normalizing as the patients recover. Other studies have also associated low serum levels of T3 and T4 with a higher mortality in sepsis and severe bacterial infections.

Even-though recent efforts into the development of an easier, faster and much more reliable diagnostic algorithm that can also serve as a predictor of outcome in postoperative sepsis related complications are encouraging, the exact role of inflammatory markers in predicting outcome in patients diagnosed with secondary peritonitis hasn't still been clarified. Existing data is scarce and evidence to support them are lacking. In the sight of these, it was aimed to investigate the prognostic values of inflammatory markers (CRP, PCT and thyroid hormones) in secondary peritonitis. PCT, CRP and thyroid hormones can be useful prognostic parameters for predicting disease severity and outcome in patients diagnosed with secondary peritonitis.

\section{MATERIALS AND METHODS}

Our study is a single center prospective cohort study conducted on patients operated on for secondary peritonitis between January 2008 and January 2010. A total of 120 patients were operated on for secondary peritonitis within the study period. Patients with localized peritonitis and those whose laboratory values (thyroid function tests, CRP and PCT) couldn't be determined were excluded from the study. $\mathrm{Pa}$ tients operated on for generalized peritonitis were included into the study. Of the 120 patients, eighty-four were found to be eligible for the study. Among the 84 patients, there were two patients with ovarian malignancy and one with colon malignancy. There were no cases of typhoid perforation.

Patients' data was reviewed and recorded into an institutional review board-approved database. The database was analyzed to identify those patients with secondary peritonitis. Patients were divided into six groups according to the diagnosis confirmed during surgery, including Group I: perforated appendicitis, Group 2: perforated peptic ulcer disease, Group 3: small bowel perforation (iatrogenic, typhoid, vasculitis), Group 4: colon perforation (iatrogenic, diverticula, foreign body), Group 5: anastomosis dehiscence, and Group 6: gallbladder perforation.

The data collected included patient demographics, and PCT, CRP, and thyroid hormone ( $\mathrm{ft} 3, \mathrm{ft} 4, \mathrm{TSH})$ concentration values of the preoperative and first, third, fifth, seventh, and fourteenth postoperative days. Informed consent was sought and approval received from each subject participating in the study.

In addition, the presence of limiting factors such as co-morbid conditions, previous drug, medical and surgical history were thoroughly investigated. Patients with previous history of thyroid surgery, usage of drugs such as beta blockers, amiodarone and steroids were determined and noted. Moreover, the absence of any other focus of infection besides peritonitis was investigated and recorded.

During the postoperative course, post-operative complications, cases of mortality developing one month after surgery and their causes were established and recorded. Post-operative early or late morbidity/mortality was defined as complications/death developing during one month or one month following surgery. The median age, PCT, CRP and thyroid hormone ( $\mathrm{ft} 3, \mathrm{ft} 4, \mathrm{TSH})$ concentration values, morbidity and mortality rates of classified groups were examined and statistical analysis was performed. 


\section{Clinical Follow-up}

At the time of admission and on the first, third, fifth, seventh, and fourteenth postoperative days, venous blood was drawn from all patients and centrifuged at $1.000 \times \mathrm{g}$ for $10 \mathrm{~min}$ at $4^{\circ} \mathrm{C}$ after a full blood cell count. All samples were tested for PCT, CRP, and thyroid hormones within 30 min after acceptance by the clinical laboratory.

Patients presented with small bowel perforation and colon perforation, two patients presented with gallbladder perforation and one patient with perforated acute appendicitis were followed up in the surgical intensive care unit. All other patients were followed up in hospital wards. During follow-up, wounds of all patients were carefully followed and appropriate anti-microbial therapy was given in cases of skin infections.

\section{Laboratory Measurements}

PCT quantification was performed using automated immunoanalysis with the Liaison analyzer (Diasorin, Saluggia, Italy). For CRP, an immunoturbidimetric assay with ADVIA Chemistry CRP_2R (Siemens Medical Solutions Diagnostics, Tarrytown, NY, USA) was used. The thyroid hormone (fT3, fT4, TSH) levels were determined using the the Sysmex XT 2000-i (Roche Diagnostics Gmb H. Mannheim, Germany) instrument.

\section{Surgical Technique}

The procedure was performed with the patients under general anesthesia. Laparotomy type was decided based on clinical, laboratory, and radiological findings at presentation. Of the twenty-one patients diagnosed with perforated appendicitis, a McBurney incision was made on 4, right para-median incision on 15 and lower midline incision (due to radiologically detected air fluid levels) on 2. An upper midline incision was employed in all other patients. Primary suture was performed in all patients diagnosed with peptic ulcer perforation. Appendectomy was performed in all patients with perforated appendectomy. For patients with perforated small bowel, primary suturing or anastomosis was performed proximal or distal to the location of perforation when abdominal contents weren't contaminated. In cases of contamination, stoma was performed. Anastomosis was performed in four patients presented with colon perforation, repair in 2 patients and stoma in 7 patients. Stoma was performed in all patients (6 in total) diagnosed with anastomosis dehiscence.

Drainage was placed in patients falling within the following category: old age, contaminated abdominal contents, or those who had the potential of developing abdominal abscesses ( $72 \%$ of all patients).

\section{Statistical Analysis}

All data was entered and analyzed using the Statistical Package for Social Sciences, version 15.0 (SPSS, Inc. Chicago, IL,
USA). Collected data was tested for normality and found to be normally distributed and were therefore expressed as mean \pm standard deviation (SD). Continuous data was evaluated using the Student's t-test and nonparametric data analyzed using the Friedman's test. Descriptive data was given as absolute numbers (percentages) or as medians (interquartile ranges or $95 \%$ confidence intervals [Cls]). Independent samples were compared using the student's t-test and non-parametric data was evaluated using the Friedman test. Statistical significance was accepted as $p \leq 0.05$.

\section{RESULTS}

Between January 2008 and January 2010, eighty-four patients undergoing surgery for secondary peritonitis were included into the study. Among these, there were perforated appendicitis $(n=21)$, peptic ulcer perforation $(n=20)$, small bowel perforation $(n=14)$ (iatrogenic, typhoid, vasculitis), colon perforation $(n=13)$ (iatrogenic, diverticula, foreign body), gallbladder perforation. $(n=3)$, and anastomosis dehiscence $(n=6)$ cases. The study included $47(56 \%)$ males and $37(44 \%)$ females with a median age of 52.3 years (15-87). The ages of patients according to the diagnosis made at presentation are shown in Table I. Thirty-four patients included in the study

Table I. The ages of patients according to diagnosis

\begin{tabular}{lcc}
\hline Diagnosis & \multicolumn{2}{c}{ Age } \\
\cline { 2 - 3 } & Mean \pm SD & Min-Max \\
\hline Perforated appendicitis & $43.9 \pm 20.2$ & $15-79$ \\
Peptic ulcer perforation & $53.8 \pm 20.1$ & $25-80$ \\
Small bowel perforation & $53.7 \pm 16.7$ & $24-87$ \\
Colon perforation & $52.6 \pm 17.6$ & $29-80$ \\
Anastomosis dehiscence & $61.1 \pm 7.6$ & $51-71$ \\
Gall-bladder perforation & $72.6 \pm 8.3$ & $66-82$ \\
\hline
\end{tabular}

Table 2. Other diseases

\begin{tabular}{lcc}
\hline Other diseases & n & $\%$ \\
\hline COPD & 6 & 7.1 \\
Coronary artery disease & 6 & 7.1 \\
Hypertension (HT) & 7 & 8.3 \\
Diabetes mellitus (DM) & 6 & 7.1 \\
Atrial Fibrillation & 2 & 2.4 \\
Polyposis Coli & 2 & 2.4 \\
Chronic liver disease & 2 & 2.4 \\
Ovarian cancer & 2 & 2.4 \\
DM-HT & 2 & 2.4 \\
Other & 15 & 17.8 \\
Absent & 34 & 40.5 \\
\hline
\end{tabular}


had no prior history of co-morbid conditions in contrast with 50 subjects who had chronic obstructive pulmonary disease (COPD) $(n=6)$, coronary artery disease $(n=6)$, hypertension $(n=6)$, diabetes mellitus $(n=2)$, chronic atrial fibrillation $(n=2)$ (Table 2). Drug history revealed no history of drug use $(n=44)$, beta-blockers $(n=\mid 4)$, steroids $(n=3)$, and insulin $(n=3)$.

The median preoperative serum PCT and CRP levels of patients in Group I ( $\mathrm{n}=2 \mathrm{I})$ were $9.9 \mathrm{ng} / \mathrm{ml}$ and $190 \mathrm{mg} / \mathrm{L}$. These values regressed to $0.19 \mathrm{ng} / \mathrm{ml}$ and $63 \mathrm{mg} / \mathrm{L}$ respectively, for both parameters on postoperative day 14 .

Median preoperative serum PCT and CRP levels of patients in Group $2(\mathrm{n}=20)$ were $10.1 \mathrm{ng} / \mathrm{ml}$ and $180 \mathrm{mg} / \mathrm{L}$. There was a decrease in serum levels of PCT to $6.7 \mathrm{ng} / \mathrm{L}$ on postoperative day 5; however, levels fluctuated between 2-3 ng/L after day 5 until postoperative day 14 . In contrast, there was a constant decrease in serum CRP levels till $78 \mathrm{mg} / \mathrm{L}$ on postoperative day 14.

The median preoperative serum PCT levels of patients in Group $3(n=14)$ showed a rather different pattern by remaining above $7 \mathrm{ng} / \mathrm{L}$ till postoperative day 7 when it began to follow a falling trend. A similar pattern was true for CRP values in this group of patients.

With the aim of determining a relationship between PCT levels and morbidity, the PCT levels of patients developing complications during follow-up and those who didn't were compared. Median preoperative PCT levels in patients developing complications (+) and those who didn't (-) were 15.5 $\mathrm{ng} / \mathrm{L}$ and $3.4 \mathrm{mg} / \mathrm{ml}$, respectively $(p=0.043)$.

The prognostic value of PCT, CRP and thyroid hormones in predicting mortality was also investigated among the groups by comparing the pre and postoperative serum levels in patients who survived and those who died during follow-up. Table 3 shows the number and percentage of patients who died and survived within each of the six groups during follow-up. Pre and postoperative serum PCT, CRP and thyroid hormone levels of patients who survived $(+)$ and those who died (-) among the various groups are illustrated in Tables 4, 5,6 , and 7 .

When the patients were further grouped into surviving $\left(^{+}\right)$ and deceased (-), the median serum CRP levels in patients with small bowel perforation on postoperative day 3 was found to be (+) $192 \mathrm{mg} / \mathrm{ml},(-) 90 \mathrm{mg} / \mathrm{ml},(p=0.036)$. Pre and postoperative data regarding CRP compared among other groups did not reach statistical significance.

The role of thyroid hormones in determining prognosis and severity in secondary peritonitis was also investigated by comparing median pre and postoperative thyroid hormone levels among complication free or bound patients and patients who survived or died during follow-up.

When results of median thyroid hormone levels in patients were compared among groups based on occurrence of complication during follow-up, they were found to be statistically significant. For complication bound $(+)$ and complication free (-) patients in Group 2; postoperative day: $3 \mathrm{T4}(+)$ 0, 83, (-) I, $46(p=0.003)$, and postoperative day 5: T4 (+) 0, 96, (-) I, $49(p=0.03 \mathrm{I})$. Complication bound $(+)$ and complication free (-) patients in Group; postoperative day I: T3 (+) 3, 58, $(-)$ I, $93(p=0.025)$, postoperative day I: TSH (+) I, 0I, (-) I, $39(p=0.03 \mathrm{I})$, postoperative day 7: T4 (+) I, 07, (-) I, 5 I $(p=0.27)$, and postoperative day 14: T3 (+) 2, 16, (-) 3,09 $(p=0,28)$. Complication bound $(+)$ and complication free $(-)$ patients in Group 4; postoperative day I: TSH (+) I, 26, (-) 2, $72(p=0.035)$, and postoperative day 7: T3 (+) I, 9I, (-) 2, $59(p=0.009)$.

Laboratory data findings in patients who survived and those who died during follow-up were also analyzed for a possible correlation. Data of surviving patients $(+)$ and patients who died (-) in the various groups revealed the following: Group 2; postoperative day 3: T4 (+) I, 37, (-) 0, $58(p=0.002)$, postoperative day 5: T4 (+) I, 39, (-) 0, $69(\mathrm{p}=0.039)$, and postoperative day 7: T3 (+) 2, 40, (-) I, $64(\mathrm{p}=0.019)$. Group 3; postop-

Table 3. Numbers of discharged and deceased patients operated on for secondary peritonitis

\begin{tabular}{|c|c|c|c|c|c|}
\hline \multirow[t]{2}{*}{ Diagnosis } & \multicolumn{2}{|c|}{ Discharged } & \multicolumn{2}{|c|}{ Deceased } & \multirow[t]{2}{*}{ Total } \\
\hline & $\mathbf{n}$ & $\%$ & $\mathbf{n}$ & $\%$ & \\
\hline Perforated appendicitis & 21 & 100 & - & - & 21 \\
\hline Peptic ulcer perforation & 13 & 65 & 7 & 35 & 20 \\
\hline Small bowel perforation & 14 & 66 & 7 & 34 & 21 \\
\hline Colon perforation & 9 & 69 & 4 & 31 & 13 \\
\hline Anastomosis dehiscence & 4 & 66 & 2 & 34 & 6 \\
\hline Gallbladder perforation & 3 & 100 & - & - & 3 \\
\hline Total & 64 & 76 & 20 & 24 & 84 \\
\hline
\end{tabular}


Table 4. Comparison of CRP, PCT and Thyroid Hormone levels among deceased and discharged patients diagnosed with peptic ulcer perforation

\begin{tabular}{|c|c|c|c|}
\hline & \multicolumn{2}{|c|}{ Peptic ulcer perforation $(n=20)$} & \multirow{3}{*}{$\mathbf{p}$} \\
\hline & \multirow{2}{*}{$\frac{\text { Discharged }(n=13)}{\text { Mean } \pm S D}$} & \multirow{2}{*}{$\frac{\text { Deceased }(n=7)}{\text { Mean } \pm S D}$} & \\
\hline & & & \\
\hline Preop. T3 & $2.18 \pm 0.61$ & $2.23 \pm 0.6$ & NS \\
\hline T4 & $1.47 \pm .040$ & $1.03 \pm 0.67$ & NS \\
\hline Thyroid-stimulating hormone & $1.64 \pm 0.89$ & $1.42 \pm 1.38$ & NS \\
\hline C-reactive protein & $150 \pm 79$ & $234 \pm 143$ & NS \\
\hline Procalcitonin & $9.30 \pm 18.65$ & $11.9 \pm 9.8$ & NS \\
\hline PostopI T3 & $1.93 \pm 0.57$ & $2.31 \pm 0.82$ & NS \\
\hline $\mathrm{T} 4$ & $1.39 \pm 0.32$ & $1.18 \pm 0.61$ & NS \\
\hline Thyroid-stimulating hormone & $1.86 \pm 1.63$ & $1.66 \pm 1.32$ & NS \\
\hline C-reactive protein & $|5| \pm 82$ & $186 \pm 84$ & NS \\
\hline Procalcitonin & $7.19 \pm 15.49$ & $5.73 \pm 2.28$ & NS \\
\hline Postop. 3 T3 & $2.29 \pm 0.76$ & $2.52 \pm 1.8$ & NS \\
\hline T4 & $1.37 \pm 0.37$ & $0.58 \pm 0.38$ & 0.002 \\
\hline Thyroid-stimulating hormone & $2.24 \pm 1.47$ & $1.15 \pm 0.73$ & NS \\
\hline C-reactive protein & $116 \pm 58$ & $173 \pm 54$ & NS \\
\hline Procalcitonin & $2.14 \pm 3.4$ & $17.9 \pm 19.5$ & 0.010 \\
\hline Postop. 5 T3 & $2.24 \pm 0.76$ & $1.44 \pm 0.28$ & NS \\
\hline $\mathrm{T} 4$ & $1.39 \pm 0.42$ & $0.69 \pm 0.34$ & 0.039 \\
\hline Thyroid-stimulating hormone & $2.48 \pm 1.75$ & $0.86 \pm 0.61$ & NS \\
\hline C-reactive protein & $119 \pm 38$ & $157 \pm 40$ & NS \\
\hline Procalcitonin & $1.27 \pm 2.37$ & $2.05 \pm 0.88$ & NS \\
\hline Postop. 7 T3 & $2.4 \pm 0.57$ & $1.64 \pm 0.18$ & 0.019 \\
\hline $\mathrm{T} 4$ & $1.46 \pm 0.35$ & $1.06 \pm 0.04$ & NS \\
\hline Thyroid-stimulating hormone & $2.22 \pm|.5|$ & $1.56 \pm 0.87$ & NS \\
\hline C-reactive protein & $62 \pm 36$ & $93 \pm 55$ & NS \\
\hline Procalcitonin & $1.92 \pm 5.68$ & $0.80 \pm 0.36$ & NS \\
\hline Postop. 14 T3 & $2.49 \pm 0.88$ & $1.44 \pm 0.33$ & NS \\
\hline T4 & $1.16 \pm 0.36$ & $0.98 \pm 0.16$ & NS \\
\hline Thyroid-stimulating hormone & $3.4 I \pm 3.72$ & $1.98 \pm 0.98$ & NS \\
\hline C-reactive protein & $80 \pm 109$ & $65 \pm 46$ & NS \\
\hline Procalcitonin & $3.88 \pm 8.45$ & $0.70 \pm 47$ & NS \\
\hline
\end{tabular}

erative day I: T3 (+) 2, 49, (-) 3, $64(\mathrm{p}=0.026)$, postoperative day 3: T4 (+) I, 45, (-) I, $00(\mathrm{p}=0.012)$, and postoperative day 7: T4 (+) I, 43, (-) 0, $87(p=0.023)$. Group 4; postoperative day I: TSH (+) 2, 54, (-) 0, $57(p=0.020)$ and postoperative day 3: $\mathrm{TSH}(+) 2,35,(-) 0,67(p=0.006)$.

We found that thyroid hormone levels changed much among patients with small bowel perforation and peptic ulcer perforation that had postoperative complications and those who died. Findings from our study showed postoperative T4 and T3 levels lower than I $\mu \mathrm{g} / \mathrm{l}$ and $3.64 \mu \mathrm{g} /$ respectively, which can be associated with a higher morbidity and mortality in these groups.

\section{DISCUSSION}

Mortality in secondary bacterial peritonitis is reported to be over $60 \%$ and known to correlate with the severity of the disease which is usually accessed by scoring systems such as the APACHE II/III and Mannheim Peritonitis Index (MPI). ${ }^{[2]}$ These scoring systems fail to distinguish between infectious and non-infectious related complications but other highly specific 
Table 5. Comparison of CRP, PCT and Thyroid Hormone levels among deceased and discharged patients diagnosed with small bowel perforation

\begin{tabular}{|c|c|c|c|}
\hline & \multicolumn{2}{|c|}{ Small Bowel Perforation $(n=2 I)$} & \multirow{3}{*}{$\mathbf{p}$} \\
\hline & \multirow{2}{*}{$\frac{\text { Discharged }(n=14)}{\text { Mean } \pm \text { SD }}$} & \multirow{2}{*}{$\frac{\text { Deceased }(n=7)}{\text { Mean } \pm \text { SD }}$} & \\
\hline & & & \\
\hline Preop. T3 & $1.95 \pm 1.67$ & $4.5 I \pm 3.37$ & 0.042 \\
\hline T4 & $1.36 \pm 0.44$ & $1.48 \pm 0.47$ & NS \\
\hline Thyroid-stimulating hormone & $\mathrm{I} .0 \mathrm{I} \pm 0.64$ & $1.42 \pm 0.87$ & NS \\
\hline C-reactive protein & $175 \pm 105$ & $130 \pm 54$ & NS \\
\hline Procalcitonin & $11.3 \pm 15$ & $6.9 \pm 5.8$ & NS \\
\hline Postop. I T3 & $2.49 \pm 1.70$ & $3.64 \pm 0.64$ & 0.026 \\
\hline T4 & $1.38 \pm 0.39$ & $1.17 \pm 0.47$ & NS \\
\hline Thyroid-stimulating hormone & $1.40 \pm 1.30$ & $0.67 \pm 0.42$ & NS \\
\hline C-reactive protein & $166 \pm 89$ & $|2| \pm 72$ & NS \\
\hline Procalcitonin & $14.7 \pm 28$ & $6.8 \pm 9.1$ & NS \\
\hline Postop. 3 T3 & $2.95 \pm 1.56$ & $2.82 \pm 0.64$ & NS \\
\hline T4 & $1.45 \pm 0.35$ & $1.0 \pm 0.16$ & 0.012 \\
\hline Thyroid-stimulating hormone & $2.35 \pm 2.94$ & $1.55 \pm 2.18$ & NS \\
\hline C-reactive protein & $192 \pm 102$ & $90 \pm 26$ & 0.036 \\
\hline Procalcitonin & $15.1 \pm 29.3$ & $2.6 \pm 3.9$ & NS \\
\hline Postop. 5 T3 & $3.0 \pm 1.59$ & $4.03 \pm 1.97$ & NS \\
\hline T4 & $1.34 \pm 0.38$ & $1.01 \pm 0.37$ & NS \\
\hline Thyroid-stimulating hormone & $2.0 I \pm 2.4 I$ & $1.33 \pm 0.38$ & NS \\
\hline C-reactive protein & $135 \pm 94$ & $128 \pm 38$ & NS \\
\hline Procalcitonin & $11.9 \pm 27.7$ & $6.0 \pm 7.0$ & NS \\
\hline Postop. 7 T3 & $3.15 \pm 1.77$ & $1.81 \pm 0.74$ & NS \\
\hline T4 & $1.43 \pm 035$ & $0.87 \pm 0.33$ & 0.023 \\
\hline Thyroid-stimulating hormone & $2.23 \pm 2.05$ & $4.54 \pm 4.0 \mathrm{I}$ & NS \\
\hline C-reactive protein & $105 \pm 77$ & $78 \pm 25$ & NS \\
\hline Procalcitonin & $7.1 \pm 13.6$ & $0.80 \pm 1.08$ & NS \\
\hline Postop. 14 T3 & $2.7 I \pm 0.8 I$ & $2.28 \pm 0.62$ & NS \\
\hline T4 & $1.47 \pm 0.33$ & $1.14 \pm 0.16$ & NS \\
\hline Thyroid-stimulating hormone & $2.62 \pm 3.61$ & $3.08 \pm 3.37$ & NS \\
\hline C-reactive protein & $66 \pm 37$ & $61 \pm 32$ & NS \\
\hline Procalcitonin & $0.90 \pm 1.50$ & $1.3 \pm 1.5$ & NS \\
\hline
\end{tabular}

diagnostic modalities such as radiological imaging procedures or percutaneous aspiration have been proven to be useful tools in predicting overall disease severity and outcome.

The clinical appraisal of inflammatory markers has gained considerable interest in identifying patients at risk for severe complications following surgical intervention ${ }^{[3-12]}$ of secondary peritonitis with recent studies identifying CRP and PCT as prospective prognostic markers in secondary peritonitis. ${ }^{[3]}$ In the sight of these, it was aimed to investigate the prognostic values of inflammatory markers (CRP, PCT and thy- roid hormones) in secondary peritonitis.

Viñas Trullen $X$ et al. prospectively enrolled fifty-seven patients into a study that found a positive and significant correlation between preoperative $\mathrm{PCT}-\mathrm{Q}$ and postoperative MPI. PCT Values $>10 \mathrm{ng} / \mathrm{ml}$ were reported to be significant for admission to the ICU and a poor clinical prognosis. ${ }^{[13]}$ In another study conducted by Nenad Ivančević et al., PCT concentrations in ninety-eight patients with acute abdominal conditions, divided into two groups namely sepsis and systemic inflammatory response syndrome (SIRs), were found 
Table 6. Comparison of CRP, PCT and Thyroid Hormone levels among deceased and discharged patients diagnosed with colon perforation

\begin{tabular}{|c|c|c|c|}
\hline & \multicolumn{2}{|c|}{ Colon Perforation $(n=13)$} & \multirow{3}{*}{$\mathbf{p}$} \\
\hline & \multirow{2}{*}{$\frac{\text { Discharged }(n=9)}{\text { Mean } \pm S D}$} & \multirow{2}{*}{$\frac{\text { Deceased }(n=4)}{\text { Mean } \pm S D}$} & \\
\hline & & & \\
\hline Preop. T3 & $2.09 \pm 0.91$ & $2.10 \pm 0.08$ & NS \\
\hline $\mathrm{T} 4$ & $1.14 \pm 0.18$ & $I . I I \pm 0.04$ & NS \\
\hline Thyroid-stimulating hormone & $3.38 \pm 3.33$ & $0.66 \pm 0.88$ & NS \\
\hline C-reactive protein & $199 \pm 176$ & $288 \pm 315$ & NS \\
\hline Procalcitonin & $7.7 \pm 4.7$ & $1.6 \pm 2.0$ & NS \\
\hline Postop. I T3 & $1.55 \pm 0.72$ & $2.07 \pm 1.20$ & NS \\
\hline T4 & $133 \pm 0.27$ & $1.16 \pm 0.22$ & NS \\
\hline Thyroid-stimulating hormone & $2.54 \pm 1.38$ & $0.57 \pm 0.43$ & 0.020 \\
\hline C-reactive protein & $172 \pm 85$ & $201 \pm 154$ & NS \\
\hline Procalcitonin & $20 \pm 33$ & $5.4 \pm 1.9$ & NS \\
\hline Postop. 3 T3 & $1.87 \pm 0.55$ & $2.4 \pm 1.75$ & NS \\
\hline $\mathrm{T} 4$ & $1.24 \pm 0.26$ & $1.25 \pm 0.32$ & NS \\
\hline Thyroid-stimulating hormone & $2.35 \pm 0.98$ & $0.67 \pm 0.51$ & 0.006 \\
\hline C-reactive protein & $146 \pm 53$ & $142 \pm 89$ & NS \\
\hline Procalcitonin & $24.2 \pm 54.8$ & $2.9 \pm 1.3$ & NS \\
\hline Postop. 5 T3 & $1.92 \pm 0.50$ & $1.73 \pm 0.68$ & NS \\
\hline $\mathrm{T} 4$ & $1.30 \pm 0.30$ & $1.12 \pm 0.48$ & NS \\
\hline Thyroid-stimulating hormone & $3.20 \pm 2.49$ & $0.92 \pm 0.74$ & NS \\
\hline C-reactive protein & $165 \pm 103$ & $|3| \pm 66$ & NS \\
\hline Procalcitonin & $2.6 \pm 3.6$ & $6.1 \pm 4.1$ & NS \\
\hline Postop. 7 T3 & $2.35 \pm 0.53$ & $1.96 \pm 0.09$ & NS \\
\hline $\mathrm{T} 4$ & $1.48 \pm 0.30$ & $1.68 \pm 0.21$ & NS \\
\hline Thyroid-stimulating hormone & $2.73 \pm 1.86$ & $1.39 \pm 0.07$ & NS \\
\hline C-reactive protein & $112 \pm 70$ & $102 \pm 3$ & NS \\
\hline PCT & $2.37 \pm 5.16$ & $0.97 \pm 0.75$ & NS \\
\hline Postop. 14 T3 & $2.39 \pm 0.43$ & - & NS \\
\hline $\mathrm{T} 4$ & $1.50 \pm 0.22$ & - & NS \\
\hline Thyroid-stimulating hormone & $2.53 \pm 1.58$ & - & NS \\
\hline C-reactive protein & $83 \pm 51$ & - & NS \\
\hline Procalcitonin & $0.4 \pm 0.6$ & - & NS \\
\hline
\end{tabular}

to be significantly higher in the sepsis group than in the SIRs group suggesting PCT as a useful criteria for early, preoperative diagnosis of abdominal sepsis. Also, in the same study, a group of patients with abdominal symptoms lasting for more than $24 \mathrm{~h}$ had higher PCT levels when compared with those with symptoms lasting less than $24 \mathrm{~h}$. This study shows a meaningful relationship between the severity of peritonitis and serum levels of PCT. ${ }^{[14]}$ Consistent with the results from these studies, our findings revealed significantly higher PCT levels in patients developing complications when compared to those who did not.
Reith and colleagues in their study reported that serum CRP and PCT levels were superior to TNF- $\alpha$, IL-I and IL-6 levels in predicting prognosis in 246 patients with abdominal sepsis, CRP and PCT levels were found to be higher in patients with postoperative infection and sepsis when compared to patients who had an uneventful postoperative course. In this study, levels of markers such as TNF- $\alpha$, CRP, IL-I, and IL-6 were reported to only increase with response to conditions like trauma and surgery. In spite of this, PCT was described to be more sensitive in sepsis and bacterial infections. ${ }^{[15]}$ 
Table 7. Comparison of CRP, PCT and Thyroid Hormone levels among deceased and discharged patients diagnosed with anastomosis dehiscence

\begin{tabular}{|c|c|c|c|}
\hline & \multicolumn{2}{|c|}{ Anastomosis dehiscence $(n=6)$} & \multirow{3}{*}{$\mathbf{p}$} \\
\hline & \multirow{2}{*}{$\frac{\text { Discharged }(n=4)}{\text { Mean } \pm S D}$} & \multirow{2}{*}{$\frac{\text { Deceased }(n=2)}{\text { Mean } \pm S D}$} & \\
\hline & & & \\
\hline Postop. I T3 & $2.24 \pm 0.78$ & $4.10 \pm 3.14$ & NS \\
\hline T4 & $1.17 \pm 0.09$ & $1.21 \pm 0.03$ & NS \\
\hline Thyroid-stimulating hormone & $1.35 \pm 0.87$ & $0.40 \pm 0.48$ & NS \\
\hline C-reactive protein & $150 \pm 102$ & $265 \pm 57$ & NS \\
\hline Procalcitonin & $10.8 \pm \mid 4.1$ & $0.55 \pm-$ & NS \\
\hline Postop. 3 T3 & $2.14 \pm 0.50$ & $5.45 \pm 2.99$ & NS \\
\hline T4 & $1.15 \pm 0.17$ & $1.23 \pm 0.62$ & NS \\
\hline Thyroid-stimulating hormone & $1.28 \pm 0.79$ & $0.21 \pm 0.26$ & NS \\
\hline C-reactive protein & $|4| \pm 86$ & $139 \pm 53$ & NS \\
\hline Procalcitonin & $9.0 \pm 14.2$ & $3.7 \pm 4.1$ & NS \\
\hline Postop. 5 T3 & $2.76 \pm 1.65$ & $7.04 \pm 3.57$ & NS \\
\hline T4 & $1.15 \pm 0.36$ & $1.21 \pm 0.61$ & NS \\
\hline Thyroid-stimulating hormone & $1.71 \pm 1.11$ & $0.04 \pm 0.02$ & NS \\
\hline C-reactive protein & $108 \pm 63$ & $124 \pm 5$ & NS \\
\hline Procalcitonin & $3.6 \pm 5.7$ & $2.1 \pm 1.4$ & NS \\
\hline Postop. 7 T3 & $2.82 \pm 0.63$ & $4.4 I \pm 3.91$ & NS \\
\hline T4 & $1.31 \pm 0.37$ & $1.09 \pm 0.26$ & NS \\
\hline Thyroid-stimulating hormone & $2.17 \pm 1.33$ & $0.13 \pm 0.11$ & NS \\
\hline C-reactive protein & $75 \pm 35$ & $161 \pm 47$ & NS \\
\hline Procalcitonin & $0.3 \pm 0.2$ & $1.16 \pm 0.96$ & NS \\
\hline Postop. 14 T3 & $3.0 \pm 1.60$ & $3.96 \pm 3.50$ & NS \\
\hline $\mathrm{T} 4$ & $1.11 \pm 0.26$ & $1.53 \pm 0.42$ & NS \\
\hline Thyroid-stimulating hormone & $2.4 I \pm 1.57$ & $0.0 \pm 0.0$ & NS \\
\hline C-reactive protein & $92 \pm 98$ & $199 \pm 55$ & NS \\
\hline Procalcitonin & $0.1 \pm 0.1$ & $2.0 \pm 2.4$ & NS \\
\hline
\end{tabular}

Bell at al., measured the serum PCT levels alone or in combination with CRP and pointed out their role in discriminating septicemia/bacteremia with associated SIRs from noninfectious SIRS in an ICU setting with 123 patients. They went on to report twelve different studies describing serum procalcitonin levels to be more important than serum CRP levels in differentiating bacterial infections from other causes of systemic inflammatory responses. ${ }^{[16,17]}$ In another study evaluating the relationship between procalcitonin, CRP and the severity of appendicitis in the pediatric population, 212 pediatric patients operated on for acute appendicitis were grouped into five groups according to surgical and histological findings. Group I had $(n=58)$ normal findings, Group 2 $(n=24)$ follicular hyperplasia, Group $3(n=66)$ acute appendicitis, Group $4(n=36)$ Perforated appendicitis, and Group $5(n=28)$ necrotizing appendicitis. Preoperative antibiotic therapy wasn't given to any of the five groups. Serum procalcitonin levels were $>0,5$ in $81 \%$ of patients in Group 4 and $64 \%$ of patients in Group 5. For CRP levels, $57 \%$ of patients in Group 4 and 32\% of patients in Group 5 had a serum CRP level greater than $50 \mathrm{mg} / \mathrm{dl}$. The clinical presentation of appendicitis was found to be severe in patients with higher serum procalcitonin and CRP levels. This showed the importance of procalcitonin and CRP as a prognostic marker in appendicitis. ${ }^{[18]}$ In our study, the median preoperative serum PCT and CRP levels of patients with perforated appendicitis $(n=21)$ were $9.9 \mathrm{ng} / \mathrm{ml}$ and $190 \mathrm{mg} / \mathrm{L}$. These values regressed to $0.19 \mathrm{ng} / \mathrm{ml}$ and $63 \mathrm{mg} / \mathrm{L}$ respectively, for both parameters on postoperative day 14. Moreover, although levels of PCT and CRP in the other five groups (perforated peptic ulcer disease, small bowel perforation (iatrogenic, typhoid, vasculitis), colon perforation (iatrogenic, diverticula, foreign body), 
anastomosis dehiscence, and gallbladder perforation) from our study remained high during the first week after surgery, a rather fluctuating pattern of PCT and CRP levels was observed towards postoperative day $\mathrm{I} 4$.

We were also able to demonstrate that serum PCT levels follow a falling trend after surgery as long as postoperative course remained uneventful. In addition, we showed that after surgical intervention for secondary peritonitis, PCT was a better marker than CRP in following postoperative complications besides peritonitis.

Thyroid hormone levels are known to decrease in situations such as infection, severe stress, trauma, and chronic conditions like cirrhosis and chronic kidney disease. ${ }^{[19,20]}$ Euthyroid sick syndrome is characterized by abnormal thyroid findings in the presence of non-thyroidal illness (NTIs) without evidence of pre- existing hypothalamic pituitary conditions. The most common alternations are low T3, normal or low T4 and normal TSH levels. This syndrome is generally associated with sepsis, malignancy, AIDS and myocardial infarction. Prognosis of patients with this syndrome is correlated with serum levels of T3 and T4. ${ }^{[21-24]}$ In our study, low T3, T4 levels among groups with higher mortality and complication rates were found.

Glembot et al. in their stimulated physiologic stress model did not see a decrease in mortality when thyroid hormones were added. ${ }^{[24]}$ In most studies, low serum T3 and T4 has been associated with a higher mortality in sepsis and severe bacterial infections. While the reported mortality ratio in patients with T4 levels lower than $3 \mu \mathrm{g} / \mathrm{dl}$ is between $64 \%$ and $84 \%$, patients with the same disease but normal thyroid levels were found to have mortality below $22 \%{ }^{[25,26]}$ We found that thyroid hormone levels changed much among patients with small bowel perforation and peptic ulcer perforation that had postoperative complications and those who died. Findings from our study showed postoperative T4 and T3 levels lower than I $\mu g / l$ and $3.64 \mu g / /$ respectively, which can be associated with a higher morbidity and mortality in these groups.

We are of the thought that PCT in addition to T3, T4 and TSH especially can be important parameters in predicting both systemic complications that may develop and the prognosis of secondary peritonitis.

Conflict of interest: None declared.

\section{REFERENCES}

1. Guarner C, Soriano G. Spontaneous bacterial peritonitis. Semin Liver Dis 1997;17:203-17. CrossRef

2. Dudley HAF. Intraperitoneal sepsis: peritonitis and abdominal abscesses. Hamilton Baileys Emergency Surgery. HA.F Dudley. Wright. Bristol 276-85.

3. Husain TM, Kim DH. C-reactive protein and erytrocyte sedimentation rate in orthopaedics. The University of Pennsylvania Orth J 2002;15:13-6.

4. Assicot M, Gendrel D, Carsin H, Raymond J, Guilbaud J, Bohuon C. High serum procalcitonin concentrations in patients with sepsis and infection. Lancet 1993;341:515-8. CrossRef

5. Harbarth S, Holeckova K, Froidevaux C, Pittet D, Ricou B, Grau GE, et al. Diagnostic value of procalcitonin, interleukin-6, and interleukin-8 in critically ill patients admitted with suspected sepsis. Am J Respir Crit Care Med 2001;164:396-402. CrossRef

6. Marshall JC, Vincent JL, Fink MP, Cook DJ, Rubenfeld G, Foster D, et al. Measures, markers, and mediators: toward a staging system for clinical sepsis. A report of the Fifth Toronto Sepsis Roundtable, Toronto, Ontario, Canada, October 25-26, 2000. Crit Care Med 2003;31:1560-7.

7. Copp DH, Davidson AG. Direct humoral control of parathyroid function in the dog. Proc Soc Exp Biol Med 1961;107:342-4. CrossRef

8. Assicot M, Gendrel D, Carsin H, Raymond J, Guilbaud J, Bohuon C. High serum procalcitonin concentrations in patients with sepsis and infection. Lancet 1993;341:515-8. CrossRef

9. Meisner M. Pathobiochemistry and clinical use of procalcitonin. Clin Chim Acta 2002;323:17-29. CrossRef

10. Baumann H, Gauldie J. The acute phase response. Immunol Today 1994;15:74-80. CrossRef

11. Beutler B, Cerami A. Cachectin: more than a tumor necrosis factor. $\mathrm{N}$ Engl J Med 1987;316:379-85. CrossRef

12. Cassatella MA. The production of cytokines by polymorphonuclear neutrophils. Immunol Today 1995;16:21-6. CrossRef

13. Viñas Trullen X, Rodríguez López R, Porta Pi S, Salazar Terceros D, Macarulla Sanz E, Besora Canal P, et al. Prospective study of procalcitonin as a diagnostic marker of the severity of secondary peritonitis. [Article in Spanish] Cir Esp 2009;86:24-8. [Abstract] CrossRef

14. Gregoric P, Sijacki A, Stankovic S, Radenkovic D, Ivancevic N, Karamarkovic A, et al. SIRS score on admission and initial concentration of IL-6 as severe acute pancreatitis outcome predictors. Hepatogastroenterology 2010;57:349-53.

15. Reith HB, Mittelkötter U, Wagner R, Thiede A. Procalcitonin (PCT) in patients with abdominal sepsis. Intensive Care Med 2000;26 Suppl 2:165-9. CrossRef

16. Bell K, Wattie M, Byth K, Silvestrini R, Clark P, Stachowski E, et al. Procalcitonin: a marker of bacteraemia in SIRS. Anaesth Intensive Care 2003;31:629-36.

17. Simon L, Gauvin F, Amre DK, Saint-Louis P, Lacroix J. Serum procalcitonin and C-reactive protein levels as markers of bacterial infection: a systematic review and meta-analysis. Clin Infect Dis 2004;39:206-17.

18. Kafetzis DA, Velissariou IM, Nikolaides P, Sklavos M, Maktabi M, Spyridis $\mathrm{G}$, et al. Procalcitonin as a predictor of severe appendicitis in children. Eur J Clin Microbiol Infect Dis 2005;24:484-7. CrossRef

19. Pearce CJ. The euthyroid sick syndrome. Age Ageing 1991;20:157-9.

20. McIver B, Gorman CA. Euthyroid sick syndrome: an overview. Thyroid 1997;7:125-32. CrossRef

21. Santini F, Chopra IJ. A radioimmunoassay of rat type I iodothyronine 5'-monodeiodinase. Endocrinology 1992;131:2521-6. CrossRef

22. Ongphiphadhanakul B, Fang SL, Tang KT, Patwardhan NA, Braverman LE. Tumor necrosis factor-alpha decreases thyrotropin-induced 5'-deiodinase activity in FRTL-5 thyroid cells. Eur J Endocrinol 1994;130:502-7.

23. Fujii T, Sato K, Ozawa M, Kasono K, Imamura H, Kanaji Y, et al. Effect of interleukin-1 (IL-1) on thyroid hormone metabolism in mice: stimulation by IL- 1 of iodothyronine 5 '-deiodinating activity (type I) in the liver. Endocrinology 1989;124:167-74. CrossRef

24. Girvent M, Maestro S, Hernández R, Carajol I, Monné J, Sancho JJ, et 
al. Euthyroid sick syndrome, associated endocrine abnormalities, and outcome in elderly patients undergoing emergency operation. Surgery 1998;123:560-7. CrossRef

25. Chopra IJ, Hershman JM, Pardridge WM, Nicoloff JT. Thyroid function in nonthyroidal illnesses. Ann Intern Med 1983;98:946-57. CrossRef

26. Arem R, Wiener GJ, Kaplan SG, Kim HS, Reichlin S, Kaplan MM. Reduced tissue thyroid hormone levels in fatal illness. Metabolism 1993;42:1102-8. CrossRef

\section{KLINIKK ÇALIŞMA - ÖZET}

\section{Sekonder peritonitte prokalsitonin, CRP ve tiroit hormonlarının prognostik değeri; ileriye yönelik çalışma \\ Dr. Idris Akcay, ${ }^{1}$ Dr. Alexis K. Okoh, ${ }^{2}$ Dr. Orcun Yalav, ${ }^{3}$ Dr. Ismail C. Eray, ${ }^{3}$ Dr. Ahmet Rencuzogullari, ${ }^{3}$ Dr. Kubilay Dalci, ${ }^{3}$ Dr. Hasan Elkan, ${ }^{4}$ Dr. Ali H. Alparslan ${ }^{3}$}

1Doc. Doktor Yasar Eryılmaz Dogubeyazıt Devlet Hastanesi, Genel Cerrahi Kliniği, Agrı;

${ }^{2}$ Ankara Üniversitesi Tıp Fakültesi, Genel Cerrahi Anabilim Dalı, Ankara;

${ }^{3}$ Çukurova Üniversitesi Tıp Fakültesi, Genel Cerrahi Anabilim Dalı, Adana;

${ }^{4}$ Balıklıgöl Devlet Hastanesi, Genel Cerrahi Kliniği, Şanlıurfa

AMAÇ: Enfeksiyon ve sepsis, sekonder peritonitli hastalarda morbidite ve mortalitenin en önemli sebeplerinden biri olmaya devam etmektedir. Klinisyenler helen septik komplikasyonların erken ve güvenilir tanı yöntemini bulma konusunda çaba sarfetmektedir. Bu çalışmada sekonder peritonitin şiddetini belirlemede enflamatuvar markır olarak Prokalsitonin (PKT), C-reaktif protein (CRP) ve tiroit hormonlarının yerini değerlendirmeyi amaçladık.

GEREÇ VE YÖNTEM: Ocak 2008-Ocak 2010 tarihleri arasında, sekonder peritonit nedeniyle ameliyat olan 84 ardışık hasta üzerinde ameliyat öncesi ve sonrası I-3-5-7-14. günlerde PKT, CRP ve tiroit hormaon seviyeleri incelendi. Veriler Statistical Package for Social Sciences I5.0 (SPSS 15.0) programında analiz edildi.

BULGULAR: Organ perforasyonu (peptik ülserperforasyonu, ince bağırsak ve kolon perforasyonu) olan olgular değerlendirildiğinde, PKT anlamlı olarak düşük seyretti. Ameliyat sonrası komplikasyonu olan veya ölen hastalara göre ameliyat sonrası dönemi sorunsuz olan veya taburcu olan hastalarada yüksek tiroit hormon düzeyler gözlendi. PKT düzeyleri ise CRP düzeylerleri ve beyaz küre sayısıyla anlamalı olarak ilişkili bulundu.

TARTIŞMA: Ameliyat sonrası komplikasyonların yokluğunda PKT, sekonder peritonit tanısında CRP'den daha iyi bir belirliyicidir. Çalışmamız sekonder peritonitin şiddetini belirlemede düşük tiroit hormon düzeylerinin önemli bir prognostik faktör olduğunu ortaya koymuştur.

Anahtar sözcükler: C-reaktif protein; prokalsitonin; sekonder peritonit; tiroit hormonları.

Ulus Travma Acil Cerrahi Derg 20।4;20(5):343-352 doi: 10.5505/tjtes.2014.98354 